\title{
"WE ARE ALL HERE TO STAY"; ADDRESSING ABORIGINAL TITLE CLAIMS AFTER DELGAMUUKW V BRITISH COLUMBIA
}

\author{
Rachel Yurkowski*
}

This article outlines how the Canadian courts dealt with the interface between aboriginal title and common law notions of property throughout the various Delgamuukw decisions. Through examination of the different judgments in the case, at different judicial levels, the article traverses issues around the source of aboriginal title, and subsequent limitations on the content of aboriginal title which arise from that. The article concludes that the unique concept of aboriginal title cannot be interpreted within the paradigm of the common law. The article further concludes that courts are the wrong forum for adjudicating aboriginal claims.

\section{INTRODUCTION}

In 1984, the Gitksan and Wet'suwet'en Indians (the Indians) brought an action against the province of British Columbia that after thirteen years, one trial, two appeals and twelve judges later, would result in "the most complete account of the law on aboriginal title that has ever been attempted by the courts." 1 The case was Delgamuukw v British Columbia ${ }^{2}$ (Delgamuukw).

* This paper was submitted in fulfilment of the LLB (Hons) requirements at Victoria University in 1999.

1 Peter W Hogg Recognition of Aboriginal Title <http://romania.saf.yorku.ca/ robarts/ canwatch/ vol_6_4,5,6/> (last accessed 24 July 1999).

2 Delgamuukw v British Columbia (1997) 153 DLR (4th) 194 (SCC) [Delgamuukw (SCC)]. 
In an attempt to alleviate the confusing case law of recent years, ${ }^{3}$ the judgment of the Supreme Court of Canada in Delgamuukw presented a new approach for determining the source, nature and content of aboriginal title, its requirements for proof, justifications for its infringement, and how and by whom it could be infringed or extinguished. Whether this approach will be upheld in future litigation is uncertain. There are significant discrepancies and anomalies in the Court's reasoning that may inhibit future claimants having their legitimate rights recognised.

These anomalies are the product of the judicial process, which has proven itself to be an unsatisfactory mechanism for determining aboriginal claims. Not only can the "winner takes all" approach of the adversarial court process result in damaging and irreversible blows for aboriginal groups, but its inflexible rules of evidence and its limited common law jurisdiction create restrictions for aboriginal claimants. Significant Commonwealth cases on aboriginal title, namely Mabo $v$ Queensland (No 2) ${ }^{4}$ (Mabo) and Wik Peoples $v$ Queensland ${ }^{5}$ (Wik) have faced the same predicament encountered by the Supreme Court in Delgamuukw. How can the doctrine of aboriginal title and its complicated sovereignty and tenure issues be reconciled with the general concepts of property at common law?

These issues suggest that a new approach to aboriginal claims be adopted, one which is not confined to the courtroom and can look beyond common law concepts of property law. The Supreme Court itself recognised the difficulties it faced and suggested future claims be addressed through negotiated settlements or specially created commissions. The author suggests these recommendations be strongly heeded, so as to avoid yet another dissatisfying denouement for aboriginal claimants.

As Tom Sampson, Chairman of the First Nations of South Island Tribal Council said of the Delgamuukw case: 6

3 For example, the Supreme Court took a generous approach to aboriginal rights in $R v$ Sparrow (1990) 70 $\operatorname{DLR}\left(4^{\text {th }}\right) 385$, yet retracted from this thinking in the 1996 cases of $R v$ Adams (1996) 138 DLR (4 $\left.4^{\text {th }}\right) 657, R$ $v$ Gladstone (1996) 137 DLR $\left(4^{\text {th }}\right) 648, R v$ Van Der Peet (1996) 137 DLR (4th) 289, $R v$ NTC Smokehouse (1996) 137 DLR (4th) 528 and $R v$ Cote $(1996) 138$ DLR (4th 385.

4 Mabo $v$ State of Queensland (No. 2) (1992) 107 ALR 1.

5 Wik Peoples $v$ State of Queensland (1996) 141 ALR 129 (HCA).

6 Tom Sampson in Frank Cassidy (ed) Aboriginal Title in British Columbia: Delgamuukw v The Queen (Oolichan Books, Lantzville and the Institute for Research on Public Policy, Montreal, 1992) 61. 
it is really not the Gitksan and Wet'suwet'en people that are on trial. It's Canada and the colonial system that is on trial. The justice system is really on trial.

In the Delgamuukw case, the justice system has lost.

\section{BACKGROUND TO THE CASE}

\section{A Common Law Aboriginal Title}

Aboriginal or native title is accepted to arise from the common law presumption that indigenous people occupied and controlled the land in accordance with traditional laws and customs prior to the introduction of British sovereignty. Upon the introduction of British governance by settlement, conquest or cession, the Crown obtains the imperium (radical title) to the land by virtue of the doctrine of tenure. This title is burdened by the native inhabitants' pre-existing legal right to the land, ${ }^{7}$ which is deemed to continue under the doctrine of continuity. ${ }^{8}$ The beneficial title (dominium) retained by the aboriginal inhabitants is known as "common law aboriginal title."

Because the Crown has the underlying title to the soil, aboriginal title is not absolute and can be infringed or extinguished by the Crown. Earlier judgments have determined that aboriginal title can only be infringed in pursuit of a "compelling and substantial objective" and with respect for the Crown's fiduciary duty towards indigenous peoples. ${ }^{9}$ This fiduciary duty

7 Guerin v Canada (1984) 13 DLR $\left(4^{\text {th }}\right) 321$ per Dickson CJ. The Judge relied on the Privy Council's statements in Amodu Tijani v Secretary, Southern Nigeria [1921] 2 AC 399, that the presumptive title of the indigenous inhabitants was based on their system of customary laws which existed prior to the cession of that territory to Britain. This was also recognised in Calder v Attorney General of British Columbia (1973) 34 DLR (3d) 145 where Judson J stated "aboriginal rights arise by operation of law, and do not depend on a grant from the Crown."

8 The doctrine of continuity as described by Brian Slattery "Understanding Aboriginal Rights" (1987) 66 Canadian Bar Review 727, 738, quoted in Delgamuukw (BCCA) per Lambert JA:

When the Crown gained sovereignty over a territory, colonial law dictated that the local customs of the native peoples would presumptively continue in force, and be recognisable in the courts, except insofar as they were unconscionable or incompatible with the Crown's assertion of sovereignty. In this respect, the rule resembles that applied in conquered or ceded colonies, where the local law is held to remain in force in the absence of acts to the contrary. But the rule respecting native custom applies regardless of whether the territory is deemed to have been acquired by conquest, cession, peaceful settlement, or in some other way. (Judge's emphasis)

$9 \quad R v$ Sparrow above $\mathrm{n} 3$. 
encompasses the requirements of consent, consultation and compensation. ${ }^{10}$ Regardless of this duty, the Crown can unilaterally extinguish title pursuant to a legislative or executive act with a "clear and plain intention" to do so. However, the obligation is upon the Crown to prove that aboriginal title has been validly extinguished or infringed. ${ }^{11}$

\section{B Aboriginal Title as a Sui Generis Interest}

Courts in recent years have classified aboriginal title as a sui generis interest, ${ }^{12}$ and the Supreme Court reaffirmed this in Delgamuukw. This was a significant development from earlier thoughts suggesting aboriginal title was a "personal and usufructuary"13 right, capable of being overridden by a Crown grant of land. However, the ramifications of granting aboriginal title a sui generis status are unclear. Is an examination of aboriginal title under common law notions of property law totally precluded or must aboriginal title be interpreted and assessed in a vacuum? Furthermore, is such a description actually valid and is it beneficial to the Aborigines' cause? ${ }^{14}$ These questions will be addressed in this paper.

\section{The Indians' Claim}

The Indians sought a declaration that they had "ownership" of 58,000 square kilometres of central British Columbia. They claimed that they and their ancestors had, since time immemorial, lived in, controlled, possessed and exercised jurisdiction over the land in accordance with their traditional aboriginal laws and customs. Having never surrendered their

$10 R v$ Symonds (1847) [1840-1932] NZPCC 387; Calder $v$ AG of British Columbia above n7, Mabo v State of Queensland above $\mathrm{n} 4$.

11 The Supreme Court in Calder above n 7, affirmed the Privy Council's principle in Amodu Tijani v Secretary, Southern Nigeria above n 7, that aboriginal rights must be "presumed to have continued to exist unless the contrary is established by the context or circumstances." Hall J elaborated, stating that "the onus of proving that the sovereign intended to extinguish the Indian title lies on the [Crown]." The same onus has been applied in $R v$ Sparrow, above $n 3$ and Simon $v R(1985) 24$ DLR $\left(4^{\text {th }}\right) 390$ (SCC), a treaty rights case, where Dickson CJ placed the burden on the Crown to lead evidence.

12 Dickson CJC first introduced the notion that aboriginal title was sui generis in Guerin $v$ Canada above $\mathrm{n}$ 7. This was reaffirmed by the Supreme Court in Paul $v$ Canadian Pacific Ltd and Roberts $v$ Canada (1989) $57 \operatorname{DLR}\left(4^{\text {th }}\right) 197$

13 St Catherine's Milling and Lumber Co v The Queen (1888) 14 AC 46, 54 (PC).

14 William Flanagan, in his article "Piercing the Veil of Real Property Law: Delgamuukw v British Columbia" (1998) 24(1) Queen's LJ 279 ["Piercing the Veil"], argues that the Supreme Court had weak grounds for classifying aboriginal title as a sui generis interest and states that if aboriginal title is analysed under common law principles, it is equivalent or superior to a fee simple estate. 
ownership by conquest or treaty, they asserted a legal right to govern the territory according to their own laws, which they claimed, at first instance, to be paramount to the laws of British Columbia. ${ }^{15}$ They accepted that the Crown held the underlying title to the soil by virtue of settlement, but did not believe that this lessened their right to ownership and self-government.

The Province of British Columbia (the Province) counter-claimed. It argued that there was no aboriginal title in British Columbia because settlement had extinguished any pre-existing systems of aboriginal law and introduced British law in its place. Under this narrow view of settlement theory, the Province argued that "the only title and rights that could exist were those granted or recognised by the Crown."16 The Province conceded that the Calder Proclamations ${ }^{17}$ passed between 1852 and 1866 had reserved the main areas of land occupied by Indians from alienation and pre-emption, and allowed Indians to use the "vacant" Crown lands for sustenance purposes. ${ }^{18}$ However, the land in these reserves did not amount to aboriginal title land, because "[i]n this scheme there was no room for other aboriginal interests." 19

\section{$D$ Decisions of the Lower Courts}

\section{Supreme Court of British Columbia 1991}

The trial in the Supreme Court of British Columbia lasted 374 days and involved, among other things, 76 witnesses, 23,503 pages of transcript evidence, 9200 exhibits and 32 binders of documents. Despite this, the result was unsatisfying for the Indians. Ignoring the uniqueness of aboriginal title, Chief Justice McEachern attempted to analyse aboriginal title within the

15 On appeal to the British Columbia Court of Appeal, the claimants rejected their initial assertion that their laws were paramount to the laws of the province. Instead they advanced a claim for selfgovernment limited to the administration and regulation of their lands.

16 Delgamuukw v British Columbia (1991) 79 DLR (4th) 185 (BCSC)) [Delgamuukw (BCSC)]. The Province's view complied with the common law doctrine of tenures and estates. As aboriginal title was neither created by Crown grant nor recognised by the Provincial government, it could not exist.

17 The Calder Proclamations were designed to foster the development of lands of the colony for settlement. Calder II stated that all lands in BC and all the minerals therein, belonged to the Crown in fee. Further ordinances (Calder IV to IX) promoted further settlement, and in 1866, Calder XIII was made to consolidate the earlier ordinances referring to the settlement of lands.

18 In the context of British Columbia, "vacant Crown lands" meant any lands that were not specifically "reserved" for Indians under the Calder III Proclamation.

19 Delgamuukw (BCSC) above n 16, 285. 
common law doctrine of tenure and estates. In doing so, he dismissed the Indians' claims of ownership and jurisdiction, concluding that aboriginal title was not a proprietary interest but rather one that existed "at the pleasure of the Crown" and had been extinguished by numerous Crown acts with the requisite "clear and plain intention." 20

Taking a "traditional white view", 21 Chief Justice McEachern disregarded the Indians' evidence, describing it as "a romantic view" 22 of the history that was "not literally true." 23

He found that the Indians' evidence of habitation on the land had not satisfied the Baker Lake test for establishing aboriginal title. ${ }^{24}$ However, he made a finding of fact that 45 square kilometres of the territory was reserve land. Having previously found that all aboriginal title had been extinguished, this seems to suggest that aboriginal title can override a Crown grant of land, which under common law has priority by virtue of its feudal origins. This proposition has significant implications that have recently been discussed in the Wik decision in Australia, but are beyond the bounds of this analysis.

McEachern CJBC also conceded some non-exclusive and non-commercial aboriginal sustenance rights exercisable on vacant Crown lands. ${ }^{25}$ These rights were limited to activities

20 The "clear and plain intention" test for extinguishment of aboriginal title and rights was developed by the USSC in United States $v$ Santa Fe Pacific Ry Co (1941) 314, 339 and adopted into Canadian jurisprudence by Chief Justice Dickson in $R v$ Sparrow, above $n$ 3. McEachern CJBC considered the Calder Proclamations as impliedly having this effect and thus concluded that all title and rights had been extinguished in the late $19^{\text {th }}$ century.

21 Paul Tennant, quoted in "Rethinking British Columbia: The Challenge of Delgamuukw" in Frank Cassidy (ed) Aboriginal Title in British Columbia: Delgamuukw v The Queen above n 6, 11.

22 Delgamuukw (BCSC) above $\mathrm{n} 16$.

23 Delgamuukw (BCSC) above $\mathrm{n} 16$.

24 Hamlet of Baker Lake v Minister of Indian Affairs and Northern Development (1980) 1 FC 518. The Baker Lake test required: 1) The claimants and their ancestors were members of an organised society; 2) the organised society occupied the specific territory over which they assert the title; 3 ) the occupation must be to the exclusion of others; and 4) that the occupation was an established fact at the time of sovereignty.

25 On the evidence, McEachern CJBC found that most of the territory was vacant land (as defined above $\mathrm{n} 15$ ) although he found that village land equating to 45 square miles of the territory had been made into a reserve pursuant to the Calder III Proclamation. This 1859 Proclamation entitled the settlers to pre-emption of unsurveyed lands, but reserved town sites, auriferous land and Indian settlements. 
"practised and used before exposure to European civilisation" 26 and arose from a fiduciary duty on the Crown. On this basis, McEachern CJBC concluded that these sustenance rights were not subject to constitutional protection under section 35 of the Constitution Act 1982,27 and accordingly would subsist until the land was dedicated to an adverse purpose, upon which they would be extinguished.

\section{British Columbia Court of Appeal 1993}

The majority decision of the British Columbia Court of Appeal was similarly unsatisfying for the Indians. Macfarlane, Taggart and Wallace J J A rejected the ownership and jurisdiction claims due to their reluctance to interfere with McEachern CJBC's findings of fact. Despite criticising the trial judge's approach to the evidence, especially his rejection of aboriginal oral histories, the appeal judges felt there was no "palpable or overriding error" 28 which would justify their intervention.

Contrary to McEachern CJBC's decision, the majority found there was no "plain and clear intention" to extinguish aboriginal rights by the provincial government prior to 1871 and accordingly recognised the existence of these rights. However, only unextinguished, nonexclusive aboriginal sustenance rights limited to "those traditions regarded by [the] aboriginal society as integral to the distinctive culture, and existing at the date sovereignty was asserted" 29 were recognised. This was because the majority subscribed to the view that aboriginal title should only extend to those practices on the land that uphold the group's connection with the land, and modern practices were incapable of doing this.

26 Delgamuukw (BCSC) above n 16, 391. This was because McEachern believed that only long-time Aboriginal uses of land could be protected under the doctrine of aboriginal title. This differs from the view taken by the SCC in $R v$ Sparrow, above $\mathrm{n} 3$, decided a year earlier, that allowed aboriginal rights to develop and modernise.

27 Constitution Act 1982, section 35(1). "The existing Aboriginal and treaty rights of the Aboriginal peoples of Canada are hereby recognised and affirmed." McEachern concluded that the protection afforded under section 35 is for "existing" aboriginal rights in 1982, whereas rights arising under a fiduciary duty are "created" by that duty at the time of judgment (compare the decision in the SCC regarding the Crown's fiduciary duty, below $\mathrm{p}$ 12).

28 Delgamuukw $v$ British Columbia (1993) 104 DLR (4th) 470, 557 per Wallace JA (BCCA) [Delgamuukw (BCCA)].

29 Delgamuukw (BCCA) above n 28, 492. This was the prevailing view of aboriginal title and rights prior to the Supreme Court judgment, and was the conclusion reached in the 1996 cases (above n 3) regarding the scope of aboriginal rights. 
Lambert and Hutcheon J J A dissented. Lambert J A's judgment was a pre-cursor to the Supreme Court's decision, in fact allowing a more extensive and unlimited right to the land than the Supreme Court. Finding that the trial judge had made substantial errors in his findings of fact, Lambert J A substituted his own findings, namely that the Indians had established historic occupation, possession, use and enjoyment of the land in accordance with their customs and traditions. He concluded that aboriginal title had been established in large parts of the territory, and unlimited sustenance rights established in those areas where title could not be found. Contrary to the majority, Lambert J A extended to the title-holders the right to use the land however they chose, not limited to uses "integral to the distinctive culture." 30 Site or activity-specific rights on land not subject to title may be limited in their contemporary execution, but, significantly, it is the: 31

aboriginal peoples' own description of the right which should control the way in which it is expressed, not the description selected by the white settlers' society to meet the needs of the settlers' society by making all aboriginal rights as narrow as possible.

\section{DECISION OF THE SUPREME COURT OF CANADA 1997}

When the highest court in the land addressed the Indians' claims, they too were unable to solve the riddle of aboriginal title. The Court refused make a definitive ruling on the basis that the trial judge had "misapprehended or overlooked material evidence,"32 and ordered a new trial to reinterpret the facts in light of the "aboriginal perspective" of the law. This new trial is yet to be heard.

At the Supreme Court, the Indians changed their claim from "ownership" to one of "common law aboriginal title." This was because it was difficult to reconcile "ownership" derived from aboriginal title and the notion of "ownership" as a fee simple estate. ${ }^{33}$ The

30 Delgamuukw (BCCA) above n 28, 648. Lambert JA rejects the "integral to the distinctive culture" test in respect of aboriginal rights (and by inference, title). Citing with approval Dickson CJ's view in $R v$ Sparrow above $\mathrm{n} 3$, he says, "...aboriginal rights are evolving rights. They are not frozen at the time of sovereignty or at any other time. The evolution which occurred before sovereignty and the evolution which occurred after sovereignty are both relevant to an understanding of the rights."

31 Delgamuukw (BCCA) above n 28, 659-60, relying on $R v$ Sparrow above $\mathrm{n} 3,1112$.

32 Delgamuukw (SCC) above n 2, 229 per Lamer CJC.

33 Amending the claim to one of aboriginal title also allowed for a decision consistent with the common law doctrine of tenures and estates and removed the difficulties raised by a claim based on a form of "allodial ownership", which was impossible under the doctrine of tenure. 
claimants did argue, however, that their right to the land equated to an inalienable fee simple estate. Furthermore, they changed their claim for "jurisdiction" to one of "self-government." If both claims were successful, aboriginal title would be an interest "significantly broader than that recognised by fee simple." 34

\section{A The Source of Aboriginal Title}

For decades the Commonwealth courts had been "vacillating between two possible sources of aboriginal title." ${ }^{35}$ It is accepted that aboriginal title arises by operation of law and pre-dates British colonisation and sovereignty, ${ }^{36}$ but the question of the source of aboriginal title has been a controversial one. Although historic occupation and use of the land by an organised society is the most widely accepted source of aboriginal title, ${ }^{37}$ other judges have alluded to a basis in the pre-existing systems of aboriginal law.

To resolve this confusion surrounding the source of aboriginal title, Lamer CJC stated that aboriginal title has a "dual source" in both historic aboriginal occupation and pre-existing systems of aboriginal law. Although historic occupation and possession are crucial to finding title under common law, aboriginal laws are an intrinsic aspect of the group's occupation of the land, and define the nature of the group's connection with the land which determines the content of aboriginal title. ${ }^{38}$ Furthermore, proof of a system of aboriginal law existing prior to

34 "Piercing the Veil" above $\mathrm{n} 14,292$. This is because self-governing rights do not accompany a fee simple estate.

35 Kent McNeil "The Meaning of Aboriginal Title," in Michael Asch (ed) Aboriginal and Treaty Rights in Canada (UBC Press, Vancouver, 1997) 135, 137. ["The Meaning of Aboriginal Title"]. Canadian, United States and New Zealand courts tend to subscribe to the "historic occupation" test, whereas the courts in Australia were more open to finding that Aboriginal systems of law existing at the time of sovereignty were sufficient to show title.

36 Guerin v Canada above n 7; Roberts above n 9, per Wilson J.

37 Justice Judson stated in Calder above $\mathrm{n}$, that aboriginal title is based on the fact that "when the settlers came, the Indians were there, organised in societies and occupying the land as their forefathers had done for centuries."

38 This accords with Brennan J's judgment in Mabo $v$ State of Queensland where he states that native title is based on the group's exclusive occupation, but the traditional laws and customs apply internally to determine the content of the rights and interests possessed by its members, known as the "incidents of native title". Mabo, above n 4, 51-52. 
sovereignty legitimises aboriginal title as a legal right pre-dating colonisation and sovereignty: 39

If aboriginal title is based simply on occupation of lands by an organised society at the time the Crown asserted sovereignty, how could it be a pre-existing right? For it to exist as a legal right before the Crown acquired sovereignty, it would need to be based on some system of law, which would have to be aboriginal, as no other law existed in North America prior to European colonisation.

\section{$B$ The Nature and Content of Aboriginal Title}

\section{Lamer CJC}

After considering both the aboriginal and common law perspectives on aboriginal title, Lamer CJC confirmed the conclusion reached in some earlier precedents that aboriginal title and rights constituted sui generis interests - neither personal, nor equivalent to fee simple ownership. His reasons for finding aboriginal title to be sui generis were threefold - its inalienability except to the Crown; its communal and collective nature; and its source in the prior occupation of lands by aboriginal people in accordance with their own pre-existing systems of law.

Under the doctrine of tenure, estates can only arise after the assertion of sovereignty. As Lamer CJC stated, "aboriginal title is a burden on the Crown's underlying title and it does not make sense to speak of a burden on the underlying title before that title exists." 40 Accordingly, the sui generis nature of aboriginal title is justified on the basis of the source of aboriginal title in pre-existing systems of aboriginal law. The Court's other bases for this classification, notably its source in possession and occupation and its communal nature are less persuasive reasons, as they can also be characteristics of common law property rights. ${ }^{41}$

Despite classifying aboriginal title as sui generis, Lamer CJC was unable to avoid analogies with common law tenets of property law. Although he dismissed the suggestion that

39 "The Meaning of Aboriginal Title" above n 35, 137.

40 Delgamuukw (SCC) above n 2, 224.

41 "Piercing the Veil" above n 14, 303-308, argues persuasively that these latter characteristics are not unknown at common law. For example, possession can be the basis of title at common law (finder's title) and title can also be held communally at common law (for example, members of a club or unincorporated society may be in concurrent occupation of their co-property). 
aboriginal title creates a fee simple estate, he concluded that it is "a right to the land itself." 42 Consequently, uses of the land are not limited to those practices exercised at the time of sovereignty or those "integral to the distinctive culture." As an exclusive right, the title-holders can determine for themselves the uses to which they put the land. They are free to engage in non-traditional uses of land such as mining, lumbering and oil and gas extraction. These rights are analogous to those of an owner of a fee simple estate. Furthermore, aboriginal title-holders can prevent others, including the government, from intruding on and using their lands without their consent. ${ }^{43}$ This final aspect exceeds the privileges possessed by a fee simple title-holder and in fact expands aboriginal title beyond any common law property right.

To distinguish aboriginal title from an interest equivalent to a fee simple estate, Lamer CJC imposed an inherent limitation upon it. In order to preserve the basis of aboriginal title (that is to say, the dual sources of aboriginal title), Lamer CJC stated that "[1]ands held pursuant to aboriginal title cannot be used in a manner that is irreconcilable with the nature of the attachment to the land which forms the basis of the group's claim to aboriginal title." ${ }^{44}$ Lamer CJC justified this limitation by referring to the sui generis status of aboriginal title.

Lamer CJC imposed a further limitation on aboriginal title. Unlike a common law proprietary interest, which arises from a Crown grant and entitles the owner to dispose of his interest to any third party, aboriginal title, as a sui generis interest, constitutes a burden on the Crown's underlying title and therefore is inalienable except to the Crown. Consequently, if an aboriginal group wishes to dispose of their interest, they must voluntarily cede their title to the Crown, who then becomes the holder of the absolute title of the land. The Crown can then grant a fee simple interest to another party, or the aboriginal group should they wish to use the land for a purpose adverse to their connection with the land.

42 Delgamuuwk (SCC) above n 2, 240. This resembles comments by Wallace JA in the BCCA that aboriginal title could amount to quite extensive interests in land, to the extent that it may resemble a common law proprietary title.

43 Therefore, any intrusion onto their lands, unless authorised by law, would be a violation of their constitutionalised rights and be an actionable trespass.

44 Delgamuukw (SCC) above n 2, 246-247, per Lamer CJC. In order to maintain the continuity between the historic patterns of occupation and present-day recognition of title, "uses of the lands that would threaten that future relationship are, by their very nature, excluded from the content of aboriginal title." 


\section{La Forest J}

La Forest J concurred with the Chief Justice's conclusion, but took a different approach. Instead of recognising a dual source of aboriginal title, he relied on the common law source of title, namely exclusive occupation and use. He rejected the notion that proof of aboriginal laws pre-existing sovereignty could be the basis of title $\mathrm{e}^{45}$ and set out four requirements to prove aboriginal title: precision as to the uses of the land, specificity as to the area, continuity of occupation and centrality. ${ }^{46}$ The aspect of centrality was paramount. "[I]f aboriginal peoples continue to occupy and use the land as part of their traditional way of life, it necessarily follows that the land is of central significance to them." ${ }^{47}$ Such centrality means that the land can only be used in ways that do not sever the significance the land has to the group. This statement accords with Lamer CJC's "inherent limitation" on aboriginal title.

\section{Proof of Aboriginal Title}

Lamer CJC emphasised the necessity to refer equally to common and aboriginal perspectives of property when analysing claims to title. ${ }^{48}$ As the common law recognises actual physical occupation and possession of land as the source of title, a claim's success would be enhanced by proof of construction of dwellings, cultivation of crops and use of regular areas of land for hunting and fishing at the time of sovereignty. ${ }^{49}$

45 La Forest J recognised that the houses' claim was stated as one of "aboriginal title", but the evidence presented sought to prove more than title - "complete control over the territory in question."They tried to show that "by virtue of their social and land tenure systems, they had acquired an absolute interest in the claimed territory, including ownership and jurisdiction over the land." He stated that their reliance on this as a basis for aboriginal title was incorrect and therefore provided the grounds for a new trial.

46 These four requirements were devised by Lamer CJC in $R v$ Van Der Peet, above n3.

47 Delgamuukw (SCC) above n 2, 281 per La Forest J.

48 This was highlighted in $R v$ Van Der Peet above $\mathrm{n} 3$ per Lamer CJC. "A court should approach the rules of evidence, and interpret the evidence that exists, with a consciousness of the special nature of Aboriginal claims, and of the evidentiary difficulties in proving a right which originated in times where there were no written records of the practices, customs and traditions engaged in. The courts must not undervalue the evidence presented by Aboriginal claimants simply because the evidence does not conform precisely with the evidentiary standards that would apply in, for example, a private law torts case."

49 The time of sovereignty being the appropriate time for determining Aboriginal occupation and use differs from the decisions in the aboriginal rights cases, such as $R v$ Van Der Peet above $\mathrm{n} 3$, where the date of first contact was deemed to be the appropriate time. Although aboriginal rights are a subset of aboriginal title, the Court felt that aboriginal rights would be best defined in terms of the society before 
The aboriginal perspective on the land could be gleaned from traditional laws, customs and practices of the people on the land, and would assist in determining the group's connection with the land. The aboriginal perspective of "exclusivity" embodies the notion of shared exclusivity, and as such, aboriginal title will not be denied where more than one group occupies or uses the land. ${ }^{50}$ Where other aboriginal groups were present in the territory, "exclusivity" involved "the intention and capacity to retain exclusive control." 51 In cases of shared occupancy, the land would be held by joint aboriginal title. ${ }^{52}$ Such a concept is not unknown at common law, 53 and thus this finding represents a conclusion based on consideration of both the aboriginal and common law perspectives of "exclusivity."

\section{Federal and Provincial Jurisdiction to Infringe or Extinguish Title}

As a "right to the land itself," aboriginal title under Lamer CJC's analysis is a real property right. Being a type of aboriginal right, it is also constitutionally protected under section 35(1) of the Constitution Act 1982. This suggests it can only be infringed upon or extinguished in

the arrival of settlers. Conversely, aboriginal title could not be recognised until the introduction of the common law. Lamer CJC acknowledged the difficulty in showing pre-sovereignty occupation and suggested groups could rely on evidence of present occupation if there was a "substantial maintenance" of the connection with the land. As long as a continued connection can be proved, present occupation will suffice in a claim for aboriginal title. La Forest J went further and said that occupation of a different territory after sovereignty could still give rise to aboriginal title in respect of that land. He acknowledged that groups which occupied a certain area prior to sovereignty may have moved to another territory after the arrival of British governance. Such relocation should not deny them a claim of aboriginal title, as they have a connection with pre-sovereignty occupation of another area. This is an admirable approach enabling groups who had been forced from their traditional territories to claim aboriginal title to other territories.

50 The nature of Aboriginal society was such that Aboriginal groups did not necessarily have the rights to use the land to the exclusion of all others. Evidence shows that territories over which particular groups asserted some means of control were not always exclusively occupied by them. Kent McNeil suggests that "where others were allowed access upon request, the very fact that permission was asked for and given would be further evidence of the group's exclusive control." Kent McNeil Common Law Aboriginal Title (Clarendon Press, Oxford, 1989) 204. Also quoted in Delgamuukw (SCC) above n 2, 259 per Lamer CJC.

51 Delgamuukw (SCC) above n 2, 259.

52 Delgamuukw (SCC) above n 2, 259 per Lamer CJC. "Shared exclusive possession is the right to exclude others except those with whom possession is shared."

53 At common law it is possible to have shared ownership and possession of land or chattels by joint tenants or tenants in common. 
exceptional circumstances for justifiable reasons. Why then does the Supreme Court justify federal and provincial infringement and extinguishment of aboriginal title?

Lamer CJC suggests that aboriginal title and rights can be infringed or extinguished subject to a test of justification. The test suggested by the Supreme Court, based on Gladstone, is a significant deviation from the liberal Sparrow test, ${ }^{54}$ as it allows, among other things, infringement in pursuit of economic goals which do not necessarily benefit the aboriginal groups. ${ }^{55}$ Should the Crown infringe aboriginal rights or title on this lenient basis, it will effectively be abrogating its fiduciary duty, which as an aspect of aboriginal title and rights is constitutionally protected. ${ }^{56}$ However, it is possible for the Crown to infringe aboriginal rights, yet still uphold its fiduciary duty, through minimum infringement, fair compensation ${ }^{57}$ and engaging in consultation with the affected group. .58

54 The $R v$ Sparrow test for justified federal legislative infringements placed the burden of proof on the government for proving that they 1) had a valid legislative objective and 2) that any infringement upheld the Crown's fiduciary duty.

$55 R v$ Gladstone above $\mathrm{n} 3$, was a commercial fishing claim. Lamer reasoned that the threshold for infringement could be lowered in such cases. The author concurs with McLachlin J in $R v$ Van Der Peet, above $\mathrm{n} 3$, when she commented how it is unacceptable and unconstitutional for the Crown to give non-Aboriginal people a "portion" of aboriginal rights.

56 Consequently the obligation to pay compensation and consult with natives is constitutional and therefore unable to be circumvented by legislation. Kent McNeil "Defining Aboriginal Rights in the 90s: Has the Supreme Court Finally Got it Right?" Robarts Centre for Canadian Studies, York University. Guest Lecture March 1999, 23 ["Defining Aboriginal Rights in the 90s"].

57 Due to the inescapable economic value of land, the Supreme Court in Guerin $v$ Canada above $\mathrm{n}$ 7, had emphasised that compensation is necessary for breaches of the Crown's fiduciary duty. This principle was embraced by the court in Delgamuukw. Whenever the Crown breaches its fiduciary duty, compensation is payable, the level of which will vary with the nature of the aboriginal title and the infringement. Compare with the situation in Australia, where under s 22 of the Native Title Amendment Act 1998 (Cth), the amount of compensation is calculated to equate to the freehold value of the land, although s 31 of the same Act requires compensation to be paid on "just terms." Maureen Tehan "Delgamuukw v British Columbia" (1998) 22(3) Melb Uni LR 763, 781.

58 Consultation is an intrinsic element of the fiduciary duty, although "the nature and scope of the duty of consultation will vary with the circumstances. In occasional cases, where the breach is less serious or relatively minor, it will be no more than a duty to discuss important decisions that will be taken in respect of lands held pursuant to aboriginal title... In most cases, it will be significantly deeper than mere consultation. Some cases may even require the full consent of the Aboriginal nation." Delgamuukw (SCC) above n 2, 265. 
The Supreme Court did not specifically address the issue of extinguishment, except to affirm that extinguishment requires an expressly "clear and plain" intention to extinguish by a legislative or executive act of the federal government. ${ }^{59}$ In Delgamuukw, the Crown did not discharge the onus to prove extinguishment by the Province, which in any case had no jurisdiction to extinguish or even infringe aboriginal title, as will be highlighted below.

In his discussion of infringement and extinguishment, Lamer CJC states that both federal and provincial governments have the authority to infringe or extinguish aboriginal rights and title. ${ }^{60}$ This explicitly contradicts his own interpretation of section 91(24) of the Constitution Act 1867, which places jurisdiction over "Indians, and lands reserved for Indians" with the federal government alone. At one stage in his judgment, Lamer CJC correctly concludes that: ${ }^{61}$

provincial governments are prevented from legislating in relation to both types of aboriginal rights. Laws which purport to extinguish those rights...touch the core of Indianness which lies at the heart of section 91(24) and are beyond the legislative competence of the provinces to enact.

However, later in his judgment, he suggests that provincial governments have the jurisdiction to infringe aboriginal title and rights through legislative instruments. He suggests that: ${ }^{62}$

the development of agriculture, forestry, mining and hydro-electric power, the general economic development of the interior of British Columbia, protection of the environment or endangered species, the building of infrastructure and the settlement of foreign populations to support those aims are justifiable infringements of aboriginal title. Initiatives in furtherance of provincial development are almost certainly facilitated by the provincial legislature.

59 Above n 27. Justice Brennan in Mabo v State of Queensland above n 4, 46 cites persuasive reasons for using such a threshold. "The requirement [of a clear and plan intention to extinguish]...flows from the seriousness of the consequences to indigenous inhabitants of extinguishing their traditional rights and interests in the land."

60 Delgamuukw (SCC) above n 2, 260 per Lamer CJC. He cites $R v$ Cote above n 3, as an example of provincial legislation justifiably infringing aboriginal rights. What he fails to observe is that $R v$ Cote concerned sustenance rights, not title, and due to its very nature, justifications for infringing title are necessarily higher.

61 Delgamuukw (SCC) above n 2, 270.

62 Delgamuukw (SCC) above n 2, 263-264. 
What Lamer CJC is suggesting is that provincial governments can act in disregard to section 91(24) of the Constitution Act 1867 and infringe constitutionally protected aboriginal rights "in pursuit of regional and economic fairness." 63

Lamer CJC's conclusion must be flawed. After 1867, the provincial government lost all constitutional jurisdiction over aboriginal title. ${ }^{64}$ Surely if aboriginal title is inextinguishable by provincial legislation, it is also unable to be infringed by provincial legislation. McNeil describes Lamer CJC's discrepancy an "an oversight, a case of the left hand having forgotten what the right hand has done." 65 In the author's view, this is not merely an oversight, but a substantial judicial error, based on a misapplication of case law ${ }^{66}$ and requires urgent redemption.

\section{E Claim for Self-Government}

By passing the issue of self-government to another trial, Lamer CJC denied himself the opportunity to set a precedent for future aboriginal self-government claims. He did suggest, however, that aboriginal title contains a community-vested decision-making authority in respect of the land. Aboriginal groups can determine to what uses they will put the land, in accordance with their internal laws, but subject to the condition that the use does not sever their connection to the land. ${ }^{67}$

$63 R v$ Gladstone above $\mathrm{n}$ 3. Lamer CJC reasoned that as Aboriginal societies exist as part of a broader social, political and economic community, it may be justifiable to infringe their rights in order to pursue compelling and substantially important objectives that benefit the whole community.

64 This has been confirmed in numerous case, including Derrickson v Derrickson [1986] 1 SCR 285; Corporation of Surrey $v$ Peace Arch (1970) 74 WWR 380.

65 "Defining Aboriginal Rights in the 90s" above n 56, 25.

66 Lamer CJC relies on his own decision in $R v$ Cote above $n 3$, to allow provincial infringement of aboriginal title. In $R v$ Cote which concerned a regulatory infringement of Aboriginal fishing rights, Lamer CJC accepted that the provincial government could infringe the rights on the basis that it was a treaty right. Lamer decided this by misinterpreting Cory J's comments in $R v$ Badger [1996] 1 SCR 771, which had allowed provincial "modification" of a treaty right on the basis of the $R v$ Sparrow test. Lamer in $R v$ Cote said "It is quite clear [from Badger] that the $R v$ Sparrow test applies where a provincial law is alleged to have infringed an Aboriginal or treaty right in a manner which cannot be justified. The text and purpose of s 35(1) do not distinguish between federal and provincial laws which restrict Aboriginal or treaty rights, and they should both be subject to the same scrutiny. " $R v$ Cote above $n 3,185$.

$67 "$ "... there is an implied recognition that the Aboriginal society must have a degree of self-government necessary to allocate the use of the land to which aboriginal title extends; to decide on utilisation 
This right is rooted in the existence of aboriginal legal systems prior to the arrival of the British settlers. ${ }^{68} \mathrm{~A}$ logical and indeed necessary extension of a legal system is a form of government, as law requires a mechanism to be exercised through. Consequently, Lamer CJC imputed that the Indians have a system of "self-government" in respect to their land.

\section{COMMENTS ON THE JUDGMENT}

The Supreme Court of Canada's decision in Delgamuukw has been hailed as the new benchmark for aboriginal claims litigation. Not only did the Supreme Court reinforce the finding in Calder that aboriginal title is recognised in British Columbia, and make some revolutionary statements on its source and content, but it also set out expanded guidelines for interpreting evidence in aboriginal claims. The Court recommended future courts to give due deference to aboriginal oral histories and anthropological evidence ${ }^{69}$ - they are part of the wider corpus of evidence, and courts should not begin with the assumption that such material is unreliable. ${ }^{70}$ Future finders of fact must acknowledge both common law and aboriginal perspectives of the law and courts must appreciate the difficulties aboriginal people face when being questioned within the context of a "foreign" legal structure.

practices; to determine which resources should be harvested and by whom; to participate in the process of consultation that would lead to justification of infringement; to agree to the amount of compensation under infringement and justification; and to decide upon the surrender of the land, if that is the wish of the people." Hon Justice Lambert "Van Der Peet and Delgamuukw: 10 Unresolved Issues" (1998) 32(2) UBCLR 249, 268 ["10 Unresolved Issues"].

68 Delgamuukw (SCC) above n 2, 242. "aboriginal title...is a collective right to the land held by all members of an Aboriginal nation. Decisions with respect to the land are also made by that community."

69 Lamer CJC implores future judges to "come to terms with oral histories of Aboriginal societies, which for many Aboriginal nations, is the only record of their past." Delgamuukw (SCC) above n 2. The Chief Justice's views accord with those of Eric Colvin who observed that "the ordinary judicial system is an inappropriate mechanism for the claims of indigenous peoples...[The] rules of evidence were not designed to handle the complex historical issues often raised by these claims." Eric Colvin, Legal Processes and the Resolution of Indian Claims (Saskatoon: University of Saskatchewan Native Law Centre, 1981) 28, cited in Geoff Sherrott "The Court's Treatment of the Evidence in Delgamuuwk v B.C." (1992) 56 Sask LR 441, 441.

70 Anthropology "begins with an assumption that Aboriginal people have evolved complex and meaningful adaptations to their environments...[and]... assumes that culture is a dynamic an living identity that continues to change and adapt to changing circumstances." Robin Ridington, cited in Brian Thom, Aboriginal Rights in Canada after Delgamuukw: Anthropological Perspectives. McGill University, Montreal, January 1999) <http://home.istar.ca/ bthom> [Anthropological Perspectives]. 
The Court found that aboriginal title is based on exclusive occupation and use of lands in accordance with customary laws prior to the assertion of British sovereignty. Aboriginal title, as a "right to the land," entitles the title-holders to an exclusive right to occupy and use the land for a full range of uses, determinable by the group, but subject to an inherent limitation - that the uses do not destroy the group's connection with the land that forms that basis of their aboriginal title. This indicates the Court's caution to extend aboriginal title to an interest comparable to a fee simple estate. Accordingly, the permitted uses of the land will necessarily be "aboriginal" uses, defined within the scope of the group's customary laws. They will be equivalent to the "incidents" of aboriginal title described by Brennan J in Mabo. Furthermore, the Court found that because of its sui generis nature, constitutionally protected aboriginal title and rights can be justifiably infringed or extinguished by federal and provincial governments. However, in respect of infringement, consultation and fair compensation are necessary to uphold the Crown's constitutional fiduciary duty.

The Delgamuukw judgment is undoubtedly significant for the jurisprudence on aboriginal title. Yet questions remain unanswered. To what extent does the source of aboriginal title in pre-existing systems of law impose limitations on the content of aboriginal title? Is this limitation justified or should aboriginal title create an interest equivalent to common law ownership? Who will determine if the limitation has been exceeded? Where does aboriginal title fit within the common law?

\section{A Aboriginal Title Claims and the Common Law}

Although the Supreme Court has renounced the application of common law principles to aboriginal rights and title cases, ${ }^{71}$ it seems unable to heed its own warning in Delgamuukw and defines aboriginal title in terms not unlike those in common law property law. Even though "[t]he need to distinguish the claim from common law tenure and notions of fee simple [was]... reflected in the change of pleadings from a claim for ownership to a claim for aboriginal title,"72 the Supreme Court continued to interpret the issue of aboriginal title under a common law framework. In doing so, it created inconsistencies in its judgment which are difficult to reconcile.

71 Lamer CJC stated the inapplicability of common law principles to such cases, as he did in another 1997 aboriginal rights case, St Mary's Indian Band v Cranbrook [1997] 2 SCR 657, where the Supreme Court referred, at 669 , to the need to "pierce the veil of real property law in adjudicating native lands rights disputes."

72 Delgamuukw above $\mathrm{n} 57,780$. 
Lamer CJC is cautious to avoid the language of "ownership" in his judgment, yet he concedes that aboriginal title is the right to "exclusive use and occupation of the land". He implies that aboriginal title is a proprietary right by describing it as a "right to the land itself" in other words, a right akin to ownership.

At common law, proof of occupancy is dependent on evidence of use. The uses relied upon to show occupancy do not limit the extent of the title. Conversely, the usual approach towards aboriginal title and rights is to define them in terms of those uses "integral to the distinctive culture of the group," thus locking aboriginal peoples in an historical time-warp in respect of the activities permitted on their lands. In Delgamuukw, Lamer CJC, contrary to his warning, adopts the wide-embracing common law approach when determining the content of aboriginal title. He states that the title-holding group can determine how it will utilise the land, which can be for any use that need not be integral to the distinctive culture. Lamer CJC suggests that mining, lumbering and oil and gas extraction could be possible uses of aboriginal title land. ${ }^{73}$

However, uncomfortable in granting aboriginal-title holders an interest equivalent to a fee simple, Lamer CJC states the sui generis nature of aboriginal title is justification for limiting the uses to which the land can be put to those that retain the group's connection with the land. These limitations maintain the "special bond"74 between historic, present and future occupation and reflect the source of aboriginal title in pre-existing systems of aboriginal law. Although Lamer CJC explicitly states the limitation does not "amount to a legal strait-jacket on aboriginal peoples who have a legitimate claim to the land," 75 it nevertheless may have the effect of freezing land uses to those defined by customary law. ${ }^{76}$

73 This is consistent with earlier Canadian and American jurisprudence which has extended aboriginal title to uses which were not traditionally exercised by the groups. Blueberry River Indian Band $v$ Canada (1995) 130 DLR (4 $\left.4^{\text {th }}\right) 193$ and United States ex rel Chunie v Ringrose (9th Cir, 1986) 788 F 2d 638, 642. "aboriginal title entitles the tribes to full use and enjoyment of the surface and mineral estate, and to resources, such as timber, on the land."

74 Delgamuukw (SCC) above n 2, 247.

75 Delgamuukw (SCC) above n 2, 249 per Lamer CJC.

76 Limiting aboriginal title to those customary rights exercised in historic times has been condemned in many judgments. The Privy Council decision in Hineiti Rireire Arani v Public Trustee [1840-1935] NZPCC 1, discouraged the freezing of rights, allowing the Maori to modify their customs in relation to their uses of the land. Similarly, Toohey J in Mabo, said modification of traditional society in itself does not mean that traditional title no longer exists. Traditional title arises from fact of occupation, not the occupation of a particular kind of society or way of life. So long as occupation by a traditional society is established now and at the time of annexation, traditional rights exist. An indigenous society 
The Court seems unable to reconcile its familiarity with the common law with its finding that aboriginal title is a sui generis interest. This results in an ambiguous statement on the content of aboriginal title. On one hand, the Court suggests aboriginal title creates an allencompassing interest in the land, allowing modern and non-aboriginal activities to be executed on the land; on the other hand, it restricts the uses of aboriginal title land to those that retain the "special bond" connecting the group's present occupation of the land with their ancestors' historic occupation. Surely activities such as mining, lumbering and mineral and gas extraction are irreconcilable with the Aborigines' connection with the land which is enhanced by their customary laws.

On which side of the fence does the Supreme Court wish to sit? It appears it cannot decide. Lamer CJC's judgment exemplifies the inconsistencies created when courts attempt to fuse the unique nature of aboriginal title with common law notions of property. His paradoxical conclusion that aboriginal title is both "all-encompassing" and "inherently limited" is an efficacious example of the inherent unsuitability of defining aboriginal title, a sui generis interest, within the confines of the common law.

The very fact that the Court classified aboriginal rights and title as sui generis interests signifies the need for an analysis independent of the common law property paradigm. However, the sui generis status of aboriginal rights and title should not be used as a justification to limit aboriginal title. As McNeil points out, if aboriginal title is based partly in its source in aboriginal law and custom, then "one would expect its content to be defined in terms of those laws and customs, which would have to be proved."77 This has the effect of limiting permissible uses of the land. Therefore, future courts should avoid relying on the unique status of aboriginal title to create an interest that may be less than if examined under other paradigms. ${ }^{78}$

Some commentators have suggested that had the Supreme Court not "pierced the veil of real property law" and instead analysed aboriginal title under common law concepts of

cannot...surrender its rights by modifying its way of life. (Mabo v State of Queensland above n 4, 150). Lamer CJ himself in $R v$ Van Der Peet, suggesting that aboriginal rights can only be those activities that are "integral to the distinctive culture," stated this rule was not applicable to aboriginal title $R v$ Van Der Peet above n 3, 320.

77 "The Meaning of Aboriginal Title" above n 35, 141.

78 "Piercing the Veil" above $n 14$. 
property, the scope of aboriginal title would be significantly wider than actually determined. Flanagan argues that: ${ }^{79}$

[a]lthough these common law principles may be "formalistic" and "alien" to aboriginal cultures, these same principles would have arguably granted to the aboriginal claimants a larger interest in their lands than was ultimately granted by the Court in Delgamuukw.

The problem with this suggestion it that it ignores the unique interest that is aboriginal title. Although the concept of aboriginal title is recognised by the common law, the two are inherently incompatible and it is misleading to define aboriginal title within such a foreign framework. If courts are to uphold the sui generis classification they have bestowed upon aboriginal title, then they ought to ignore real property law concepts, which only serve to confuse the issue. If this results in an unduly limited scope for aboriginal title, then courts may have to reassess their approach to aboriginal title claims. Should they be struggling to determine the status of aboriginal title and how it fits, if at all, into the common law, or should they rather concentrate their efforts on creating equitable solutions that satisfy aboriginal claimants as well as the government?

\section{B Overseas Approaches to Aboriginal Title and the Common Law}

Unlike the Supreme Court of Canada, courts in other jurisdictions have not hesitated in defining aboriginal title within a common law property law framework. This is perhaps initiated by a desire to create for aboriginal claimants an interest equivalent to a Crown granted fee simple estate. However, these good intentions have muddied the waters surrounding the real meaning of aboriginal title.

Contrary to the sentiments of the Canadian Supreme Court, several jurisdictions have described aboriginal title as entitling groups to "ownership" of the land, disregarding the meaning of this term at common law. At common law, "ownership" encompasses the broadest right of all to land, entitling the owner to use the land however he or she desires, (subject to resource management restrictions) and pass it on to to any successor they choose. Brennan $\mathrm{J}$ in Mabo believed the inalienability of aboriginal title did not preclude it from equating to "ownership". He reasoned: 80

79 "Piercing the Veil" above n 14, 323.

80 Mabo $v$ State of Queensland above n 4, 51 per Brennan J. This qualifies his earlier statement that "the nature and incidents of native title must be ascertained with reference as a matter of fact to those [traditional] laws and customs." (above $\mathrm{n} 4,58$.) 
[w]hile it is true that Native title, unlike most estates in fee simple, is inalienable other than by surrender to the Crown....it would be wrong to point to the inalienability of land...to deny that the indigenous people owned their land....[t]he ownership of land within a territory in the exclusive occupation of a people must be vested in that people; land is susceptible of ownership, and there are no other owners.

Other courts have expressed similar views, describing aboriginal title as "full beneficial ownership" of the land, allowing the title-holder to engage in any activity they desire upon the land. ${ }^{81}$ American courts in particular have held that aboriginal title "extends to exclusive use and enjoyment irrespective of the original nature of the attachment to the land." 82 In 1823 , Marshall CJ in Johnson $v M^{\prime}$ Intosh ${ }^{83}$ stated that "[the Indians] were admitted to be the rightful occupants of the soil, with a legal as well as just claim to retain possession of it, and to use it according to their discretion." 84

Some courts have even used the terminology of "fee simple" to describe the aboriginal interest in land. In 1835, the Court in Mitchel $v$ United States ${ }^{85}$ described the aboriginal peoples' right of occupancy "as sacred as the fee-simple of the whites," and Toohey J in Mabo implied that native title is as good as a fee simple. ${ }^{86}$ These judgments were based on an overriding principle of equality, attempting to give aboriginal title "full respect" and equality with common law proprietary title-holders. This is a desirable principle to abide by, but in applying it to aboriginal title claims, the law has been further confused as to the applicability of common law notions to aboriginal title.

81 Johnson $v$ M'Intosh (1823) 8 Wheat 543 and Mitchel $v$ United States (1835) 34 US (9 Pet) 711 in the United States, and Amodu Tijani v Secretary, Southern Nigeria above n 7, and Geita Sebea v Territory of Papua (1941) 67 CLR 544, from the Privy Council.

82 Richard Bartlett "The Content of Aboriginal Title and Equality Before the Law" (1998) 61 Sask LR, 391.

83 Johnson $v M^{\prime}$ 'Intosh above $\mathrm{n} 81$.

84 Johnson $v M^{\prime}$ Intosh above n 81, 574. Further at 574, Chief Justice Marshall qualified this by stating that aboriginal title was "necessarily, to a considerable extent, impaired", although "the rights of the original inhabitants were, in no instance, entirely disregarded." Richard Bartlett above n 82 interprets Marshall CJ's limitation extending only as far as was necessary to give the Crown sovereignty.

85 Mitchel $v$ United States above n 81.

86 Mabov State of Queensland above $\mathrm{n} 4$. 
Applying common law notions of property law to aboriginal title creates inconsistencies in the definition of the content of aboriginal title. Describing aboriginal title as a "fee simple estate" or the right of "ownership" has created a false impression of aboriginal title as an absolute proprietary interest, to be used at the title-holder's discretion. It is acceptable, even desirable, to allow aboriginal title-holders some measure of self-determination as to how they will use their lands, but in doing so, the special nature of aboriginal title must not be ignored. By its very nature as an inalienable, sui generis interest, aboriginal title is unable to be a platform from which a freehold, fee simple interest equivalent to "ownership" can be created. It is not a title created by grant nor is it a common law tenure - its source is in historic occupation in accordance with customary laws, and accordingly, the uses for which it can be put can only be defined by those customs, albeit modified versions of them.

\section{A NEW APPROACH}

\section{A Aboriginal Title Claims in the Courts}

Kent McNeil has posed the question, "has the Supreme Court finally got it right?" The answer can only be an equivocal one. Yes and no.

The Supreme Court comprehensively analysed the source and nature of aboriginal title, and established revolutionary guidelines for its proof, but erred on the issue of provincial jurisdiction to infringe or extinguish aboriginal title. In the end, the Supreme Court refused to address the substantive issues of whether aboriginal title and self-government had actually been made out, so after thirteen years of courtroom battles, massive expenditure and, undoubtedly, psychological exhaustion, the Indians remain where they began - empty-handed.

What the case has proven is that courts are the wrong forum for aboriginal claims. The common law rules of evidence, although relaxed by the Supreme Court, are a significant hurdle for aboriginal claimants, and the adversarial nature of the judicial process is not favourable to such claims. Furthermore, the time and cost involved is often excessive, and wasted if a determination is never reached. The Court itself admitted it was not the appropriate forum for addressing aboriginal claims, instead recommending a process of negotiation where the two parties could consult with each other outside and decide on a solution without the constrictions of the common law. ${ }^{87}$ In short, the common law paradigm is unsuitable for

87 Delgamuukw (SCC) above n 2, 284, per La Forest J. "The best approach in these types of cases is a process of negotiation and reconciliation that properly considers the complex and competing interests at stake." 
assessing the content of a sui generis interest such as aboriginal title. A new approach is required for such claims.

\section{B New Paradigms for Resolving Aboriginal Claims}

The fundamental rights of the indigenous peoples, arising from their historic occupation of the land in accordance with customary laws, demand full respect. The economic advancement of the province through the exploitation of the rich natural resources on the land also deserves consideration. The only effective way of achieving an equilibrium between indigenous and private land rights is through consultation and co-operation via specially created commissions and negotiated treaty settlements. As Lamer CJC muses, "We are all here to stay." 88

Indigenous land claim settlements by treaty and legislation have become the most effective mechanism for resolving aboriginal claims. The Canadian government, like the governments of Australia, New Zealand and the United States, among others, has taken this administrative approach to resolving aboriginal claims, which has proven considerably more successful than litigation. ${ }^{89}$ Contrary to the legal process, the settlement process has "pro[ved] that accommodations between indigenous and non-indigenous peoples are possible." 90

In 1993, the federal government of Canada stated its intention to adhere to a policy of whereby: ${ }^{91}$

comprehensive claims settlements are negotiated to clarify the rights of aboriginal groups to land and resources, in a manner that will facilitate their economic growth and contribute to the development of aboriginal self-government.

In the same year, the province of British Columbia established the British Columbia Treaty Commission to facilitate a six-stage treaty-making process in the province to settle indigenous land claims. The agreement between the federal and provincial governments and the British

88 Delgamuukw (SCC) above n 2, 273.

89 For example, the Nisga'a accord, signed in 1996 yet awaiting ratification by the Canadian government, resolved 28 years of litigation (Calder $v$ Attorney General of British Columbia above n 7). In 1999, the selfgoverning Nuvunak territory was established in Northern Canada. This came about not through litigation, but as a result of negotiated agreements and legislative actions.

90 Ken Coates and Paul McHugh Living Relationships - Kokiri Ngatahi - The Treaty of Waitangi in the New Millennium (VUW Press, Wellington, 1998) 41 [Living Relationships].

91 Hon Tom Siddon, PC, MP Minister of Indian Affairs and Northern Development. "Federal Policy for the Settlement of Native Claims" March 1993, quoted in Living Relationships above n 90, 130. 
Columbia First Nations Summit to establish the Commission shows a commitment to "improve the relationship among parties." 92 The Commission cannot make binding orders or determinations, similar to the Waitangi Tribunal in New Zealand, but has persuasive recommendatory powers. One can only speculate how the Gitksan and Wet'suwet'en Indians would have fared had they chosen this avenue to resolve their claim. In the future, the Treaty Commission ought to be the starting point for any aboriginal claim in British Columbia.

Although the usual treaty process involves extinguishing aboriginal title and making a Crown grant of land to Indians with full beneficial ownership rights, following Delgamuukw, First Nations have made a more radical statement to the Ministers under the first stage of the treaty process. They are demanding that there be no extinguishment of aboriginal title and that aboriginal rights that are granted equate to jurisdiction over the land. Whether these requests will be accepted is uncertain. What is clear, however, is that a negotiated treaty settlement process is the only means by which aboriginal groups can have their claims heard equitably.

\section{CONCLUSION}

After a long struggle, the Gitksan and Wet'suwet'en's plea remains unanswered. The new trial ordered by the Supreme Court implies that the Delgamuukw case "will remain part of the judicial landscape for many years." 93

The Supreme Court's comments on aboriginal title are likely to form the basis for the pleadings at the new trial. If aboriginal title is found to exist on the evidence, which would be very likely, the application of the Supreme Court's test will still deny the Indians their end goal. They will not be able to use their lands like freehold owners. They must surrender their aboriginal title if their use of the land negatives the basis of their title. Simply, the limitation on their land uses will render them "prisoners of the past." 94

The court has tried to interpret a unique concept, that of aboriginal title, within the strict and conservative paradigm of the common law. The Delgamuukw case has proven that this model does not work. The only way to resolve the complex issues arising from aboriginal

92 Living Relationships above $\mathrm{n} 90,132$. This was the aim stated by the Commission in their annual report in 1997.

93 Tehan, above n $57,781$.

94 "Defining Aboriginal Rights in the 90s" above n 56, 12. 
claims is through negotiated settlements, involving specially created commissions and legislative action.

The judgment in Delgamuukw has "set the political stage for re-defining the fundamental relationship between the Canadian State and aboriginal peoples." 95 Aboriginal groups can only go forward from here. The path they choose will determine their success.

95 Anthropological Perspectives above $\mathrm{n} 70,1$. 